\title{
Nutrition and health-related quality of life among people with hypertension
}

\author{
Alimentação e qualidade de vida relacionada à saúde de pessoas com hipertensão arterial \\ sistêmica
}

\section{Nutrición y calidad de vida relacionada con la salud de personas con hipertensión arterial}

Patrícia Costa dos Santos da Silva ${ }^{1}$, Silvana Maria Coelho Leite Fava ${ }^{2}$, Juliana Pereira Machado ${ }^{3}$, Simone Maria Muniz da Silva Bezerra ${ }^{4}$, Michelle Pita Tavares Gonçalves ${ }^{1}$, Eugenia Velludo Veiga ${ }^{1}$

\begin{abstract}
Aimed at analyzing the association between diet and health-related quality of life of people with systemic arterial hypertension. A descriptive-analytic study of 397 hypertensive people conducted from April to July 2013 attended by a family health strategy center unit in south Minas Gerais, MG, Brazil. The Minichal instrument was used for evaluating health-related quality of life and another instrument was used for nutrition. The average value found in the Minichal instrument was 4.2 in the mental state domain and 3.4 in the domain of somatic manifestations. Most participants had partially adequate nutrition; $67.8 \%$ mentioned not receiving any advice or treatment for weight loss; obesity was present in 35.5\%. It was concluded that diet is significantly associated with mental state.
\end{abstract}

Descriptors: Feeding; Quality of life; Hypertension; Primary Health Care; Nursing.

Foi objetivo analisar a associação entre alimentação e qualidade de vida relacionada à saúde de pessoas com hipertensão arterial sistêmica. Estudo descritivo-analítico com 397 pessoas hipertensas cadastradas em uma unidade de estratégia de saúde da família do Sul de Minas Gerais, MG, Brasil, realizado de abril a julho de 2013. Utilizou-se o instrumento Minichal para a avaliação da qualidade de vida relacionada à saúde e outro para a alimentação. Encontrou-se o valor médio de 4,2 no domínio estado mental e 3,4 no domínio manifestações somáticas do instrumento Minichal. A maioria apresentou alimentação parcialmente adequada; 67,8\% mencionaram não terem recebido orientação ou tratamento para perda de peso; a obesidade esteve presente em 35,5\%. Concluiu-se que a alimentação apresentou associação estatisticamente significante com o estado mental.

Descritores: Alimentação; Qualidade de vida; Hipertensão; Atenção Primária a Saúde; Enfermagem.

El objetivo fue analizar la asociación entre nutrición y calidad de vida relacionada con la salud de personas con hipertensión arterial sistémica. Estudio descriptivo, analítico, con 397 personas hipertensas inscritas en una unidad de la Estrategia de Salud Familiar del sur de Minas Gerais, MG, Brasil, realizado entre abril y julio de 2013. Se utilizó el instrumento Minichal para evaluar la calidad de vida relacionada con la salud y otro para nutrición. Se encontró el valor promedio de 4,2 en el dominio estado mental y 3,4 en el dominio manifestaciones somáticas del instrumento Minichal. La mayoría presentó nutrición parcialmente adecuada; $67,8 \%$ afirmaron no recibir orientación o tratamiento para pérdida de peso; la obesidad estuvo presente en 35,5\%. En conclusión, la nutrición presentó asociación significativa con el estado mental.

Descriptores: Alimentación; Calidad de vida; Hipertensión; Atención Primaria de Salud; Enfermería.

\footnotetext{
${ }^{1}$ Escola de Enfermagem de Ribeirão Preto, Universidade de São Paulo. Ribeirão Preto, SP, Brazil.

${ }^{2}$ Universidade Federal de Alfenas. Alfenas, MG, Brazil.

${ }^{3}$ Centro Universitário Barão de Mauá. Ribeirão Preto, SP, Brazil.

${ }^{4}$ Universidade Federal de Pernambuco. Recife, PE, Brazil.
}

Corresponding author: Costa dos Santos da Silva

Av. Bandeirantes, 3900, Campus Universitário, Monte Alegre, CEP: 14040-902 - Ribeirão Preto, SP, Brazil. E-mail: patriciacostaunifenas@ hotmail.com 


\section{Introduction}

Systemic Arterial Hypertension affects approximately one billion people worldwide; approximately 7.1 million deaths annually can be attributed to systemic arterial hypertension. Although silent, this highly prevalent disease compromises the health of many people and requires complex and expensive care, unless detected early and treated adequately from the beginning of the disease process $^{(1)}$.

Scientific studies have identified poor health-related quality of life among people with Systemic Arterial Hypertension ${ }^{(2-4)}$. However, we still do not know the exact relationship or importance of each of the factors responsible for the poor perception of people with hypertension on their health-related quality of life, especially with regards to non-pharmacological treatment which requires changes in lifestyle. These changes include the adoption of a low calorie diet, weight reduction, physical activity, reducing alcohol intake and/or salt, being the most effective ways and that generate less cost in terms of public health ${ }^{(5-6)}$.

Recent systematic literature review examined whether there was adequate evaluation of the effects of dietary interventions on health-related quality of life, regardless of weight loss and what instruments are used to measure the health-related quality of life and nutrition, as well as identify the gaps in the literature and suggest future directions ${ }^{(7)}$. This study also highlights the importance of considering the dietary recommendations in general for all individuals that can affect the health-related quality of life in both positive and negative directions, when one considers that there is no weight loss or improved health ${ }^{(7)}$.

In this sense, there are few studies that evaluate the influence of food on health-related quality of life among people with systemic arterial hypertension. Considering the importance of such research to better understand the perception of people with Systemic Arterial Hypertension as well as investigate the behaviors that influence their lifestyle, the association between diet and health-related quality of life in people with Systemic Arterial Hypertension enrolled in a Family Health Strategy Unit of a municipality in the southern region of Minas Gerais was the objective of this study.

The objective of this study was to analyze the association between diet and the health-related quality of life of people with systemic arterial hypertension registered in a Family Health Strategy unit.

\section{Methods}

A descriptive-analytic study of a quantitative approach carried out from April to July 2013 in a Family Health Strategy Unit of a municipality in southern Minas Gerais, part of a larger study entitled "Qualidade de vida relacionada à saúde entre hipertensos atendidos em unidades de estratégia de saúde da família" done by the Research Group Project Workshop sphygmomanometer, Ribeirão Preto, University of São Paulo School of Nursing.

The study population was represented by 2599 registered people of both gender (1207 men and 1392 women). Of these, 1956 (890 men and 1066 women) were included in the age group above 18 years. Out of this, 512 people $(26.1 \%)$ had been diagnosed with systemic arterial hypertension, with 210 men and 302 women. Initially, a pilot study was conducted with 30 people with Systemic Arterial Hypertension enrolled in the Hiperdia system of the Family Health Strategy Unit which were not part of the study, with the aim of this study to obtain data for the calculation of the sample and verify the best way to collect and record data, identify people's understanding of the issues and to verify the need for adequate vocabulary. Later, there were adjustments to the instrument, which has undergone a refining process (validation of appearance), in order to verify that its items represented the universe of content and were capable of fulfilling the objective.

The sample was calculated by the Open Epi, Version 2, after the pilot study execution. $20 \%$ of participants were added to $n=369$, totalling 443 people. 
This increase is considered important to ensure that even in the event of losses, the statistical power remains at $80 \%$. Thus, the population consisted of 512 people with systemic arterial hypertension, with 443 people being drawn to take part in the study sample. Of the 443 people randomly selected for the study, 46 did not meet the inclusion criteria, a total sample of 397 people.

The inclusion criteria were: being registered in the Family Health Strategy Unit, being 18 years of age or older and having a medical diagnosis of systemic arterial hypertension. Exclusion criteria: people who did not have conditions to answer the questions or that after three visits were not at home.

For data collection, interviewers were selected (students in the eighth period/semester of the nursing course and nurses), who were trained by the researcher responsible for the study to fill out the instrument questionnaire and anthropometric assessment. A questionnaire was used to assess sociodemographic characteristics, as well as the specific Minichal instrument to assess health-related quality of life ${ }^{(8)}$.

This instrument was translated and validated to be used with the Brazilian population. Minichal evaluates the fields related to mental status ( 9 questions) and the somatic manifestations (7 questions). It presents a subjective question to see how the individual feels about hypertension and its treatment regarding its influence on their health-related quality of life. The responses of the fields and subjective questions are distributed on a Likert frequency scale, with four options for answers 0 (Not at all) to 3 (Yes, really). On this scale, the closer to 0 the result, the better the health-related quality of life. The domain of mental state comprises questions 1-9, with a maximum score of 27 points. The somatic manifestations domain comprises questions 10 to 16 and has a maximum score of 21 points $^{(8)}$.

For dietary assessment, we used the question- naire proposed by the Food Guide for the Brazilian population, provided by the Ministry of Health to encourage healthy eating ${ }^{(9)}$. The questionnaire includes 18 questions about characteristics related to eating patterns, the practice of physical activity, water and alcohol intake, and for the calculation of the total score, one should observe their responses and add the corresponding score. This guide was written based on the current epidemiological situation (epidemiological and nutritional transition), with the purpose to promote dietary guidelines aimed at health promotion and prevention of diseases related to diet. As for non-transmissible chronic diseases, there are mellitus diabetes, obesity, cardiovascular disease, cancer and hypertension ${ }^{(9)}$. To categorize eating habits, with a score of up to 28 points there is the need to make healthier eating and living habits, that is, the score is inadequate; 29 to 42 points, there is the need for attention to diet and other habits such as physical activity and consumption of liquids, i.e., the score is partially suitable; 43 points or more, diet and lifestyle are adequate $^{(9)}$.

To calculate the body mass index (BMI), anthropometric data such as height and weight were measured. Body weight $(\mathrm{Kg})$ was checked with the person wearing light clothes; standing upright; without shoes; with the legs together and arms positioned along the body; with the palms facing the $\operatorname{leg}^{(10)}$. Weight was measured once, using a portable digital scale with a maximum capacity of $150 \mathrm{Kg}$ and variation of $100 \mathrm{~g}$. Height $(\mathrm{cm})$ was measured with the establishment of an inelastic tape measure on a vertical surface without baseboards; with the individual barefoot; unadorned head; standing; with heels together, and with the buttocks, shoulders, and head touching the vertical surface of the wall, adopting the horizontal line of sight at the moment of inspiration ${ }^{(10)}$.

The body mass index (BMI) was calculated with the measurements of weight and height, according to the formula BMI=weight $(\mathrm{kg}) / \mathrm{height}^{2}(\mathrm{~cm})$. The BMI 
cut-off points were underweight (BMI <18.5); normal weight (BMI $\left.18.5-24.9 \mathrm{Kg} / \mathrm{m}^{2}\right)$; overweight $(25.0 \mathrm{Kg} /$ $\left.\mathrm{m}^{2} \leq \mathrm{BMI} \leq 29.9 \mathrm{Kg} / \mathrm{m}^{2}\right)$ and obesity $\left(\mathrm{BMI} \geq 30 \mathrm{Kg} / \mathrm{m}^{2}\right)^{(11)}$.

The application of the form occurred in homes of people with hypertension, after scheduling with them in order to avoid interference in daily activities.

Quantitative and descriptive data were analyzed, typed, double-entry, and stored in an Excel spreadsheet. There was consistent double-checking of the original interview fields when necessary for correction.

To verify the relationship between the power and the health-related quality of life of people with hypertension, the data were entered into SPSS software version 15.0. For the choice of tests, the Kolmogorov-Smirnov test was performed first to verify the normal distribution of the sample; as the sample was not normally distributed, we used the non-parametric Kruskal-Wallis test. In all analyzes we considered a significance level of $5 \%$.

The research project was approved by the Research Ethics Committee of the Ribeirão Preto School of Nursing, University of São Paulo, according to the protocol no 02313012.4.0000.5393.

\section{Results}

Data from this study revealed a predominance of females $(244 ; 61.5 \%)$. In terms of age, three $(0.8 \%)$ aged between $19-29$ years; five (1.3\%) between 30 to 39 years; 40 (10\%) between 40 and 49 years; 96 (24.2\%) between 50 and 59 years and 253 (63.7\%) over 60 years.

For marital status, 40 (10.1\%) were single; $228(57.4 \%)$ were married or in a stable relationship; $34(8.6 \%)$ were divorced or separated; 95 (23.9\%) were widowed. Regarding family monthly income, 37 (9.6\%) received less than the minimum wage; 190
(49.2\%), one to two minimum wages; 85 (22\%), above two salaries up to three minimum wages; 74 (19.2\%), more than three minimum wages and 11 (2.8\%) did not know.

As for education, 31 (7.8\%) were illiterate; 210 (53\%) had incomplete primary education; 76 (19.1\%) had completed primary education; 16 (4.0\%) had not completed high school; 37 (9.3\%) had completed high school and 27 (6.8\%) had a college education. With reference to occupation, 105 (26.4\%) do not perform paid work and 292 (73.6\%) have paid work.

In relation to body mass index in Table 1, a prevalence of BMI above 25 can be seen, with 158 (39.8\%) classified as overweight and 141 (35.5\%) classified as obese.

Table 1 - Distribution of people with hypertension, according to the variable of body mass index

\begin{tabular}{|c|c|c|c|c|c|}
\hline $\begin{array}{l}\text { Body Mass Index } \\
(\mathrm{n}=394)^{*} \mathrm{Kg} / \mathrm{m}^{2}\end{array}$ & n (\%) & Average & Amplitude & Median & $\begin{array}{l}\text { Standard } \\
\text { Deviation }\end{array}$ \\
\hline $\begin{array}{l}\text { Underweight } \\
(\leq 18.5)\end{array}$ & $6(1.5)$ & 28.2 & 15.2 to 50.3 & 28.8 & 5.4 \\
\hline $\begin{array}{l}\text { Normal weight } \\
\text { (18.5 a } 24.9 \text { ) }\end{array}$ & $89(22.4)$ & & & & \\
\hline $\begin{array}{l}\text { Overweight ( } 25 \\
\text { to } 29.9 \text { ) }\end{array}$ & $158(39.8)$ & & & & \\
\hline Obesity ( $\geq 30$ ) & $141(35.5)$ & & & & \\
\hline
\end{tabular}

*Three participants did not have their BMI calculated due to difficulty to remain standing for measurements

In regards to data on the receipt of guidance or treatment for weight loss in Table 2, most do not receive any guidance or treatment. As for diet, the majority do not follow any special diet. Referring to nutrition, most of them are partially adequate. In the scoring range, the median was 39 points, with values ranging from 23 to 52.3 , averaging 39 points and a standard deviation of 5.6 points. 
Table 2 - Hypertension patients distribution ( $\mathrm{n}=397)$, according to weight loss supervision or treatment, special diet, type of diet and nutrition

\begin{tabular}{lc}
\hline Variables & $\mathbf{n}(\%)$ \\
\hline Following weight loss supervision or treatment & \\
Yes & $128(32.2)$ \\
No & $269(67.8)$ \\
Special diet & \\
Yes & $141(35.5)$ \\
No & $256(64.5)$ \\
Type of diet & \\
Diabetic diet & $40(10.1)$ \\
Diabetic and low sodium diet & $16(4.0)$ \\
Low-fat diet & $4(1.0)$ \\
Low-sodium diet & $60(15.1)$ \\
Weight loss diet & $18(4.5)$ \\
Lactose-free diet & $1(0.3)$ \\
None & $256(64.5)$ \\
Other diets (laxative, ulcer) & $2(0.5)$ \\
Nutrition levels & $103(25.9)$ \\
Inadequate & \\
Partially adequate & \\
Adequate & $277(69.8)$ \\
\hline & \\
& \\
&
\end{tabular}

In this study, the results from the evaluation on health-related quality of life of people with hypertension were obtained through the Minichal instrument domain values of mental state, ranging from 0 to 26 , with an average of 4.2 .

The other domain of somatic manifestations met the range of 0 to 18 with an average value of 3.4, with the variation of scores for this domain being $0-18$ which states that the closer to zero, the better the health-related quality of life; on the other hand, the closer to 18 , the worse the health-related quality of life.

The last question of Minichal, question no 68, "Would you say that your systemic arterial hypertension and treatment have affected your quality of life?" had a 0.2 average.

The score levels proposed in the questionnaire indicated in the Ministry of Health's Nutrition Guide are presented in Table 3, and the results (inappropriate, partially adequate and appropriate) were associated with the areas of mental state and somatic manifestations. There was a statistically significant association $(\mathrm{p}<0.05)$, indicating that people with inadequate nutrition have a worse health-related quality of life.

Table 3 - Nutrition, mental state and somatic manifestations of Minichal scale

\begin{tabular}{|c|c|c|c|c|c|c|c|}
\hline \multirow{2}{*}{ Nutrition (levels) } & \multicolumn{4}{|c|}{ Mental State } & \multicolumn{3}{|c|}{ Somatic manifestations } \\
\hline & P25* & $\begin{array}{l}\text { Medi- } \\
\text { an }\end{array}$ & $\mathrm{P}^{*} 5^{* *}$ & p-value & P25 & $\begin{array}{l}\text { Medi- } \\
\text { an }\end{array}$ & P75 p-value \\
\hline Inadequate $(\leq 28)$ & 2.5 & 5.0 & 9.0 & $0.001^{* * *}$ & - & 3.0 & $6.50 .067^{* * *}$ \\
\hline $\begin{array}{l}\text { Partially adequate } \\
(29-42)\end{array}$ & 1.0 & 3.0 & 7.0 & & - & 3.0 & 5.5 \\
\hline Adequate $(\geq 43)$ & - & 1.0 & 3.0 & & - & 1.0 & 3.0 \\
\hline
\end{tabular}

\section{Discussion}

The present study showed a predominance of women aged over 60 years, showing that the highest percentage of hypertension found among women may be related to their greater tendency for self-care and the increased demand for health services among women when compared to men. The low percentage of men in the study in general points to the need for greater coordination between the use of epidemiological information systems with the field of scientific research aimed at elaborating improvement, evaluation and monitoring focused on health policies for $\operatorname{men}^{(12)}$.

With regard to marital status, the study results indicate prevalence of people with systemic arterial hypertension married or living with a partner, which shows resemblance to a study investigating the presence of depression, the ability to perform activities of daily living and cognitive function among older adults with systemic arterial hypertension developed in the 
same geographic region ${ }^{(13)}$. When it comes to people married or living with a partner, the literature states that health professionals should encourage the participation of the spouse or partner in supporting the care of family in the treatment of hypertension, and thus promote better adherence to treatment and consequent disease control ${ }^{(14)}$.

As for education, the highest percentage of people with hypertension (53.3\%) had incomplete primary education, reflecting low education. These data corroborate other studies in people with systemic arterial hypertension having completed less than four years of study ${ }^{(13-15)}$. In this context, the multidisciplinary team should identify possible difficulties related to the treatment of hypertension, as the low level of education can be an obstacle to understanding and learning instructions ${ }^{(14)}$.

In terms of occupation, most mentioned not performing paid work, which can be attributed to the fact of the large number of female participants and performing activities at home. In an international study which evaluated the health-related quality of life among people with hypertension, in terms of occupation they found $37.1 \%$ unemployed; $13 \%$ employed; $26.7 \%$ government employees; $12.2 \%$ self-employed and $10.6 \%$ with other occupations ${ }^{(16)}$.

This study found that most participants had BMI above $25 \mathrm{Kg} / \mathrm{m}^{2}$. Obesity proved alarming among respondents.

An international study showed the estimated prevalence of obesity as $19.9 \%$ in adults aged 18-64 years ${ }^{(17)}$. Furthermore, there is a relationship between BMI and blood pressure (PA), and the prevalence of obesity in the hypertensive population throughout the world $^{(18,19)}$.

For nutrition, it became clear that the majority had partially adequate. The Brazilian population still live in a developing country and thereby still suffer from inadequate nutrition, such as hunger, malnutrition and obesity. On the other hand, it appears that healthy eating habits are embedded in cultural, economic and political structures, which are not always able to change. For these changes to occur, it is fundamental that more emphasis be put on promoting policies aimed at determining these habits ${ }^{(20)}$.

Another fact that stands out is that although most participants having a BMI above $25 \mathrm{Kg} / \mathrm{m}^{2}$ and are registered in a Family Health Strategy unit, most also reported that they had never received any kind of guidance for control or weight loss or to go on any special diet. It is worth noting that it is important that these results may be used to support educational strategies and/or actions that may contribute to a healthier diet.

As for the health-related quality of life, it can be observed that by comparing the results of this study with other national and international research using the Minichal, the average obtained in the areas of mental state and somatic manifestations have similar data $^{(8.21)}$.

In the present study, a statistically significant difference in the field of Minichal scale mental state and nutrition assessment was observed with the $\mathrm{Kru}$ skal-Wallis test. Higher scores in the field of mental state among people with systemic arterial hypertension who have inadequate food was also found, or have health-related quality of life lower than those who eat right or have partially adequate nutrition.

In a recent systematic review which brought together 24 studies on dietary interventions and the health-related quality of life, based on the findings there was a lack of data to support that the implementation of a diet that positively or negatively affects perception of health-related quality of life. While it is widely accepted that it is not a disadvantage to encourage healthy people to change their diets, the results of this review with overweight and obese people to eat more fruit and vegetables or eat fewer calories suggest that it is not yet clear whether making changes in diet translates into improved health-related quality of life, regardless of the individual weight loss ${ }^{(7)}$.

Although studies that evaluated the health-related quality of life using the Minichal scale emphasize the importance of nutrition in the prevention and 
treatment of Systemic Arterial Hypertension, none of them used special tools for assessing the diet with anthropometric indicators frequently found such as BMI, waist circumference, waist-hip ratio to assess obesity and consequently eating habits ${ }^{(8,15,22-24)}$.

One limitation of this study that can be mentioned is the fact that it only covered one family health strategy unit which was done for convenience. Therefore, it is proposed that further research be undertaken with an aim towards diet and the association to health-related quality of life in other communities. Research like this can serve as a reference for further studies to implement educational strategies that encourage people to aquire healthier eating habits.

\section{Conclusion}

The study found a predominance of women aged 50-69 years; incomplete primary education; Systemic Arterial Hypertension diagnosis time of over 10 years. Overweight and obesity are a reality among people with systemic arterial hypertension. In addition, the majority reported not having received guidance or treatment for weight loss and follow a partially adequate nutritional diet.

There was statistically significant association only in the field of Minichal scale mental state and diet through the use of the Kruskal-Wallis statistical test.

The team work of the family health strategy unit, especially nurses, for health education becomes essential with appropriate strategies of socio-cultural conditions in order to promote health and stimulate the acquisition of healthy eating habits that are part of the treatment for systemic arterial hypertension.

\section{Collaborations}

Silva PCS and Fava SMCL contributed to the study design, literature review, data analysis and writing of the article. Machado JP and Bezerra SMMS contributed to the critical review and final draft of the article. Gonçalves MPT contributed to the critical anal- ysis of the article. Veiga EV contributed in the design of the study, critical review and final wording of article.

\section{References}

1. Theodorou M, Kaitelidou D, Galanis P, Middleton N, Theodorou P, Stafylas P, et al. Quality of life measurement in patients with hypertension in Cyprus. Hellenic J Cardiol. 2011; 52(5):407-15.

2. Saleem F, Hassali MA, Shafie AA. A cross-sectional assessment of health-related quality of life (HRQoL) among hypertensive patients in Pakistan. Health Expect. 2014;17(3):388-95.

3. Trevisol DJ, Moreira LB, Fuchs FD, Fuchs SC. Health-related quality of life is worse in individuals with hypertension under drug treatment: results of population-based study. J Hum Hypertens. 2012;26(6):374-80.

4. Carvalho MV, Jardim PCB, Sousa ALL. A influência da hipertensão arterial na qualidade de vida. Arq Bras Cardiol. 2013; 100(2):164-74.

5. Mensah GA, Bakris G. Treatment and control of high blood pressure in adults. Cardiol Clin. 2010; 28(4):609-22.

6. Sociedade Brasileira de Cardiologia, Sociedade Brasileira de Hipertensão, Sociedade Brasileira de Nefrologia. VI Diretrizes Brasileiras de Hipertensão. Arq Bras Cardiol. 2010; 95:1-51.

7. Carson TL, Hidalgo B, Ard JD, Affuso O. Dietary interventions and quality of life: a systematic review of the literature. J Nutr Educ Behav. 2014; 46(2):90-101.

8. Schulz RB, Rossignoli P, Correr CJ, FernándezLlimós F, Toni PM. Validação do mini-questionário de qualidade de vida em hipertensão arterial (MINICHAL) para o português (Brasil). Arq Bras Cardiol. 2008; 90(2):139-44.

9. Ministério da Saúde (BR). Guia de alimentação [internet]. 2012 [citado 2014 out 16]. Disponível em:http://nutricao.saude.gov.br/teste_ alimentacao.php

10. Peres MA, Masiero AV, Longo GZ, Rocha GC, Matos IB, Najnie K, et al. Auto-avaliação da saúde em adultos no Sul do Brasil. Rev Saúde Pública. 2010; 44(5):901-11. 
11. World Health Organization. Physical status: the use and interpretation of anthropometry. Geneva: World Health Organization [Internet]. 1995 [cited 2014 Out 16]. Available from: http://whqlibdoc. who.int/trs/WHO_TRS_854.pdf?ua=1

12. Schwarz E, Gomes R, Couto MT, Moura EC, Carvalho SA, Silva SFC. Política de saúde do homem. Rev Saúde Pública. 2012; 46(1):108-16.

13. Silva PCS, Monteiro LA, Graciano ADS, Terra FS, Veiga EV. Assessment of depression in elderly with systemic hypertension. Rev Rene. 2014; 15(1):151-7.

14. Tavares DMS, Martins NPF, Dias FA, Diniz MA. Qualidade de vida de idosos com e sem hipertensão arterial. Rev Eletr Enf [periódico na Internet]. 2011 [citado 2014 out 16];13(2):2118. Disponível em: http://www.fen.ufg.br/revista/ v13/n2/pdf/v13n2a07.pdf

15. Bezerra SMMS, Veiga EV. Quality of life among people with hypertension served in units of family health strategies. J Nurs UFPE on line [periódico na Internet]. 2013 [cited 2014 Out 16]; 7 (12):705563. Disponível em: http://www.revista.ufpe.br/ revistaenfermagem/index.php/revista/article/ view/5203/pdf_4254

16. Ucan O, Ovayolu N. Relationship between diabetes mellitus, hypertension and obesity, and healthrelated quality of life in Gaziantep, a central south-eastern city in Turkey. J Clin Nurs. 2010; 19(17/18):2511-9.

17. Sardinha LB, Santos DA, Silva AM, Coelho-e-Silva MJ, Raimundo AM, Moreira $\mathrm{H}$, et al. Prevalence of overweight, obesity, and abdominal obesity in a representative sample of Portuguese adults. PLoS One. 2012; 7(10):47883.
18. Nguyen T, Lau DC. The obesity epidemic and its impact on hypertension. Can J Cardiol. 2012; 28(3):326-33.

19. Vyssoulis GP, Karpanou EA, Liakos CI, Kyvelou SM, Tzamou VE, Michaelides AP, et al. Cardiovascular risk factor(s) prevalence in Greek hypertensives. Effect of gender and age. J Hum Hypertens. 2012; 26(7):443-51.

20. Vinholes DB, Assunção MCF, Neutzling MB. Frequência de hábitos saudáveis de alimentação medidos a partir dos 10 Passos da Alimentação Saudável do Ministério da Saúde: Pelotas, Rio Grande do Sul, Brasil. Cad Saúde Pública. 2009; 25(4):791-9.

21. Badia X, Roca-Cusachs À, Dalfó A, Gascón G, Abellán J, Lahoz R, et al. Validation of the short form of the Spanish Hypertension Quality of Life Questionnaire (MINICHAL). Clin Ther. 2002; 24(12):2137-54.

22. Melchiors AC, Correr CJ, Pontarolo R, Santos FOS, Souza RAP. Qualidade de vida em pacientes hipertensos e validade concorrente do MINICHALBrasil. Arq Bras Cardiol. 2010; 94(3):357-64.

23. Soutello ALS, Rodrigues RCM, Jannuzzi FF, Spana TM, Gallani MCBJ, Junior WN. Psychometric performance of the Brazilian version of the Mini-cuestionario de calidad de vida en la hipertensión arterial (MINICHAL). Rev Latino-Am Enfermagem. 2011; 19(4):855-64.

24. Bündchen DC, Santos RZ, Antunes MH, Souza CA, Herdy AH, Benetti M, et al. Quality of life among hypertensive patients in outpatient treatment and exercise programs. Rev Bras Cardiol. 2010; 23(6):344-50. 